\title{
The effect of light rail transit service on nearby property values: Quasi-experimental evidence from Seattle
}

\author{
Michael R Ransom \\ Brigham Young University \\ ransom@byu.edu
}

\begin{abstract}
This paper examined the effect of the construction of light rail transit stations on surrounding residential property values in Seattle, Washington. It studied sales of homes in the areas around the seven stations that serve primarily residential areas in the Rainier Valley, using a difference-in-differences regression technique to obtain plausibly causal estimates of the effect of new rail service. For these seven stations, the estimated impact of light rail service was positive for only one station and negative for two stations. Estimated impacts for the other stations were small and statistically insignificant. These results suggest that light rail service did not provide value to the neighborhoods in the Rainier Valley of Seattle. I speculate that the transport service provided by light rail was not a significant improvement relative to the bus lines that serviced the area before light rail was built.
\end{abstract}

\section{Article history:}

Received: November 7, 2016

Received in revised form: August 17, 2017

Accepted: December 28, 2017

Available online: May 16, 2018

\section{$1 \quad$ Introduction}

This paper analyzes the impact of new light rail service on the price of residential property in Seattle, Washington in the United States. Light rail has been popular with local transit agencies in North America. Since 1990, more than 20 cities in the United States have built new light rail lines or expanded existing lines. Planners generally believe that these systems will improve transit access, reduce dependency on automobiles, and that stations will provide a focal point for high density development. However, the systems are very expensive to build and to operate. For example, the construction cost of the system studied here, Seattle’s Central Link "starter," was $\$ 2.7$ billion (Lindblom, 2016). Furthermore, in the 2014 fiscal year, operating costs for Seattle’s light rail exceeded fares by about $\$ 45.5$ million (Federal Transit Authority, 2016), and fares covered only about 26 percent of operating costs.

Understanding the impact of new light rail service on housing prices is important for at least two reasons. First, it provides market based evidence of whether light rail provides improved transportation access compared to transit systems in place before light rail was built. If residents place value on the new transport option, this value should be capitalized into house prices where that access is available. Another reason to study the impact on property values is that many proponents of rail systems have proposed that new light rail systems might be financed with "value capture" schemes, whereby the tran-

Copyright 2018 Michael R Ransom

http://dx.doi.org/10.5198/jtlu.2018.1096

ISSN: $1938-7849$ | Licensed under the Creative Commons Attribution - Noncommercial License 4.0

The Journal of Transport and Land Use is the official journal of the World Society for Transport and Land Use (WSTLUR) and is published and sponsored by the University of Minnesota Center for Transportation Studies. This paper is also published with additional sponsorship from WSTLUR. 
sit agency uses the uplift in local land values as a source of revenue (Higgins \& Kanaroglou, 2016; Lari et. al., 2009). If light rail does not increase real estate values, this method for financing will fail.

There is no shortage of studies that estimate the impacts of transit projects on nearby property values. Higgins and Kanaroglou (2016) document 60 separate studies from North America alone, some of which examine multiple locations or outcomes. However, only a small number of these studies provide results that are plausibly causal. For example, the vast majority of the studies documented by Higgins and Kanaroglou are cross-sectional. That is, they look at how housing prices vary at different distances from rail stations at a point in time and interpret these differences to mean that the presence of the station is the source or cause of the differences. However, this ignores the fact that rail stations are not sited randomly, and this approach will likely lead to biased estimates of the impact. For example, if light rail stations are purposely located to serve areas with high numbers of jobs, higher housing values may be due to the easy access to employment in the area, not the rail service. On the other hand, if a rail line is in a blighted area because it is easy to acquire right-of-way there, then the estimated impact of the rail stations that serve the area may be biased downward. Cross sectional studies are likely biased because important characteristics of the station locations are not captured in the variables used in the models.

In response to such concerns, a new thread of research uses quasi-experiments to eliminate these biases. Examples are Pope and Pope (2015), Figlio and Lucas (2004), or Black (1999). Parmeter and Pope (2012) provide a detailed description of quasi-experimental methods as applied to hedonic pricing models of the housing market. One such method relies on difference-in-differences estimators, which are used in this study. Difference-in-differences estimates compare house prices in areas served by light rail before and after initiation of service (the first difference), comparing this change with changes in prices for houses in nearby neighborhoods that are far from light rail stations (the second difference).

\section{$2 \quad$ History of Seattle's central link light rail}

In November 1996, voters in King, Pierce, and Snohomish counties approved sales and excise tax increases that would fund a regional transit plan called "Sound Move." This included plans for a 34 kilometer (21-mile) long light rail transit line that would connect the University District of Seattle to SeaTac Airport, originally estimated to cost $\$ 1.7$ billion. Over the following eight years, the plan faced many legal and financial challenges. In late 2001, the board of Sound Transit (the transit agency that built and operates the light rail line) approved a shorter 22.5-kilometer (14-mile) line that would connect downtown Seattle to SeaTac. The estimated cost of this shorter line, dubbed "Central Link" was \$2.1 billion (Pryne, 2001). The agency began to purchase property for the right-of-way in mid-2002 and construction was scheduled to being in summer of 2002, but it was still not certain that all the funding necessary for would become available (Pryne, 2002). Construction actually began in November 2003, after the final funding approval was received (Sound Transit, no date). Up to that date, it was uncertain if the light rail line would actually be built.

The light rail system began operation between Westlake Station in downtown Seattle and Tukwila/ International Boulevard Station in February 2009, with a bus bridge to SeaTac Airport. Direct rail service to the airport commenced in December 2009. Final construction cost of the line was $\$ 2.7$ billion. Further expansion of the system from Westlake Station to the University of Washington was completed in 2016 at an additional cost of $\$ 1.8$ billion (Linbdblom, 2016). The trip from SeaTac to downtown Seattle currently (2017) takes about 35 minutes and the fare is $\$ 3.00$. 


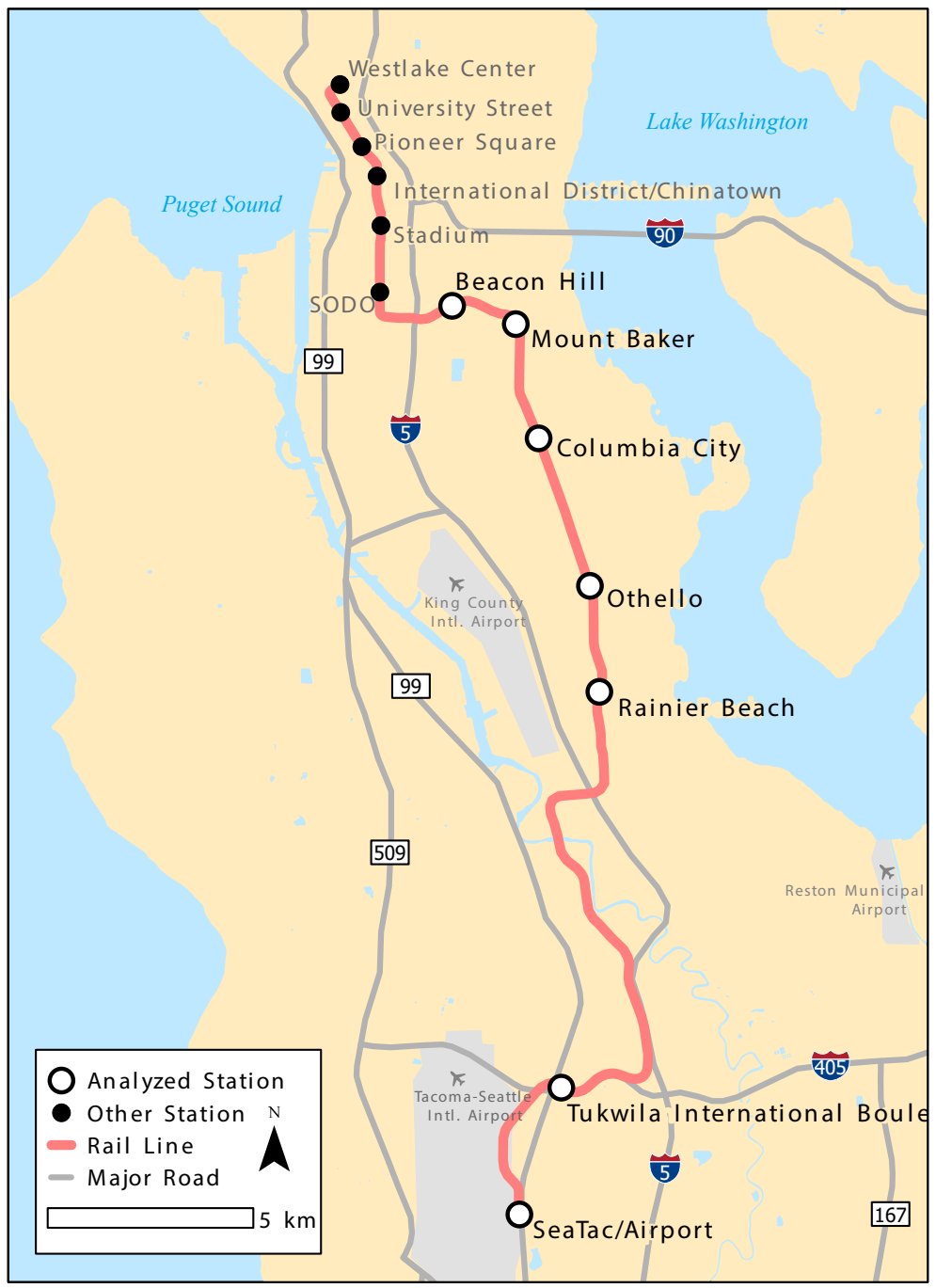

Figure 1: Seattle's Central Link light rail network during study period (Created by Brandon Whitney, ThinkSpatial)

This analysis focuses on the original 22.5-kilometer segment, which includes 13 stations. Figure 1 shows a map of the system. The six stations between SODO and Westlake are not located in residential neighborhoods - there are few, if any, single family homes within walking distance of these stations. Therefore, this study analyzes housing prices in neighborhoods of the seven southernmost stations of the line-from Beacon Hill to SeaTac Airport.

In these areas, the light rail line runs primarily along surface streets. However, between Mt. Baker and SODO stations the line runs through a tunnel. At Beacon Hill, elevators take riders to the underground station where they can board the train. In that sense, Beacon Hill is different from other stations, as trains do not operate on the surface in the area.

This analysis focuses on two dates from which to estimate the differences-in-differences: 2009, when the line actually opened, and 2004 (actually, late 2003) when financing of the system was finalized and construction began, at which point it became clear that the system would be built. These two dates represent different ideas about how people might perceive the benefits of light rail. If consumers are 
sufficiently forward-looking, they will recognize that in the future locations near light rail stations will provide better transportation services, and that consumers who value these services will be willing to pay higher prices for homes in those locations. The expectation of higher prices in the future will potentially lead consumers to offer higher bids today. If this is the case, the 2004 date is the relevant date on which to base the analysis. On the other hand, if consumers are not forward-looking, or if they are unaware of the value of transportation services until the services are actually available, then 2009 would be the appropriate date for the comparison.

\section{Data}

The data on which this paper is based comes from the King County Department of Assessments. ${ }^{1}$ The department provides a number of downloadable files that include characteristics of all real estate parcels in King County, as well as a sales history for each of these parcels. The study sample consists of single family residential parcels that sold between January 1, 1992, and March 31, 2016. Parcels with multiple buildings, sales that included multiple parcels, as well as sales that may have involved duress, such as bankruptcies have been excluded, as well. Many of the recorded transactions in the assessor's data set are not actually full-interest sales of the property. These transactions represent gifts, transfers, trades, grants or sales of easements, corrections, and so forth. These are excluded from the sample. A small number of houses whose sale price was less than $\$ 50,000$ were also removed from the sample, as these prices seem too low to represent true market transactions. However, this exclusion has no noticeable impact on the results.

The location of each parcel and the light rail stations was identified using Geographic Information System data from the King County GIS Data Center. ${ }^{2}$ Using GIS software, the parcels were mapped and those parcels that are within 800 meters ( 0.5 mile) and those within 3200 meters ( 2 miles) of a light rail station were identified. A house is defined to be in the "neighborhood" if it is within 3200 meters of the station unless it is closer to another light rail station. A house is defined to be in the catchment area of a rail station if it is within an 800-meter radius of the station, unless it is closer to another station. (Straight-line distances are used to delineate these areas, not actual walking distances.) The 800-meter distance is generally accepted as defining the catchment area of a transit station, as it about the distance that someone can walk in 10 minutes. ${ }^{3}$ The 3200 -meter radius that I use to define a neighborhood is somewhat more arbitrary. The objective is to identify a comparison group of houses that are similar to those in the catchment area of a station in terms of the neighborhood characteristics, distance from the city center, and so forth, but are far enough away from the station that travel on the light rail network would require more than a walk to the station. Figure 2 shows the neighborhood and rail catchment area for the Beacon Hill and Mount Baker stations. Parcels that appear in darker color are those included in the analysis sample - that is, they are single-family residential parcels that sold between 1992 and 2016.

\footnotetext{
${ }^{1}$ The Department's website is http://info.kingcounty.gov/Assessor/DataDownload/default.aspx.

2 The King County GIS Data Portal is located at http://www5.kingcounty.gov/gisdataportal/.

${ }^{3}$ Guerra and Cervero (2013) provide empirical support for this notion based on analysis of transit stations in residential neighborhoods in a number of US cities.
} 


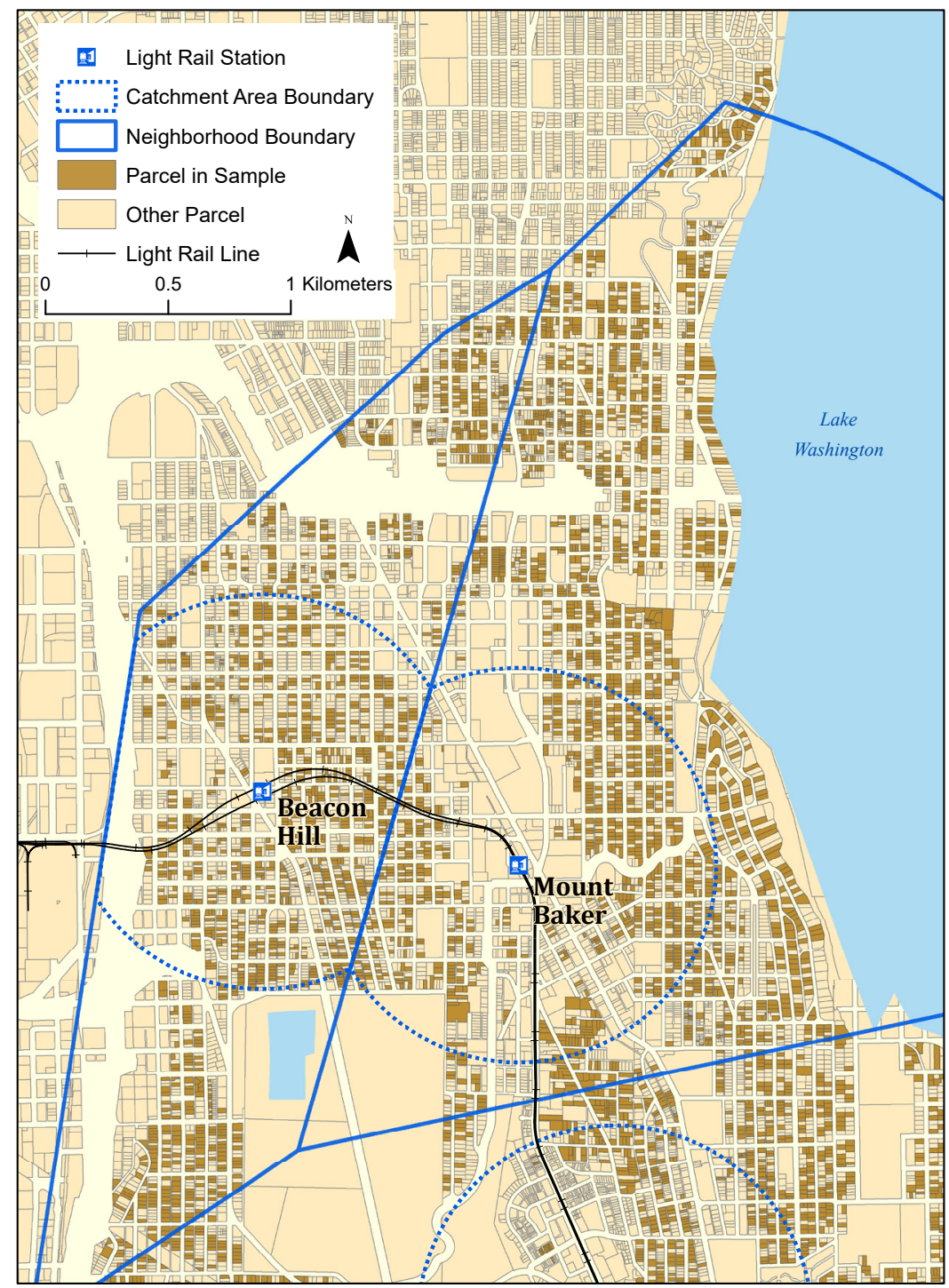

Figure 2: Study area detail—Beacon Hill and Mount Baker neighborhoods.

To account for housing price inflation, the sale price of each house is adjusted using the CaseSchiller price index for the Seattle metro area. ${ }^{4}$ Thus, the analysis explains changes in the real relative price- that is, the price of houses in station neighborhoods relative to houses that sold in the same period in all parts of Seattle metro area. I have also explored estimating a hedonic price index, and the results obtained are very similar. However, using the Case-Schiller index simplifies the analysis while providing a well-understood benchmark.

\footnotetext{
${ }^{4}$ The Case-Schiller index is available through the web site of the Federal Reserve Bank of St. Louis, at https://fred.stlouisfed. org/series/SEXRNSA.
} 


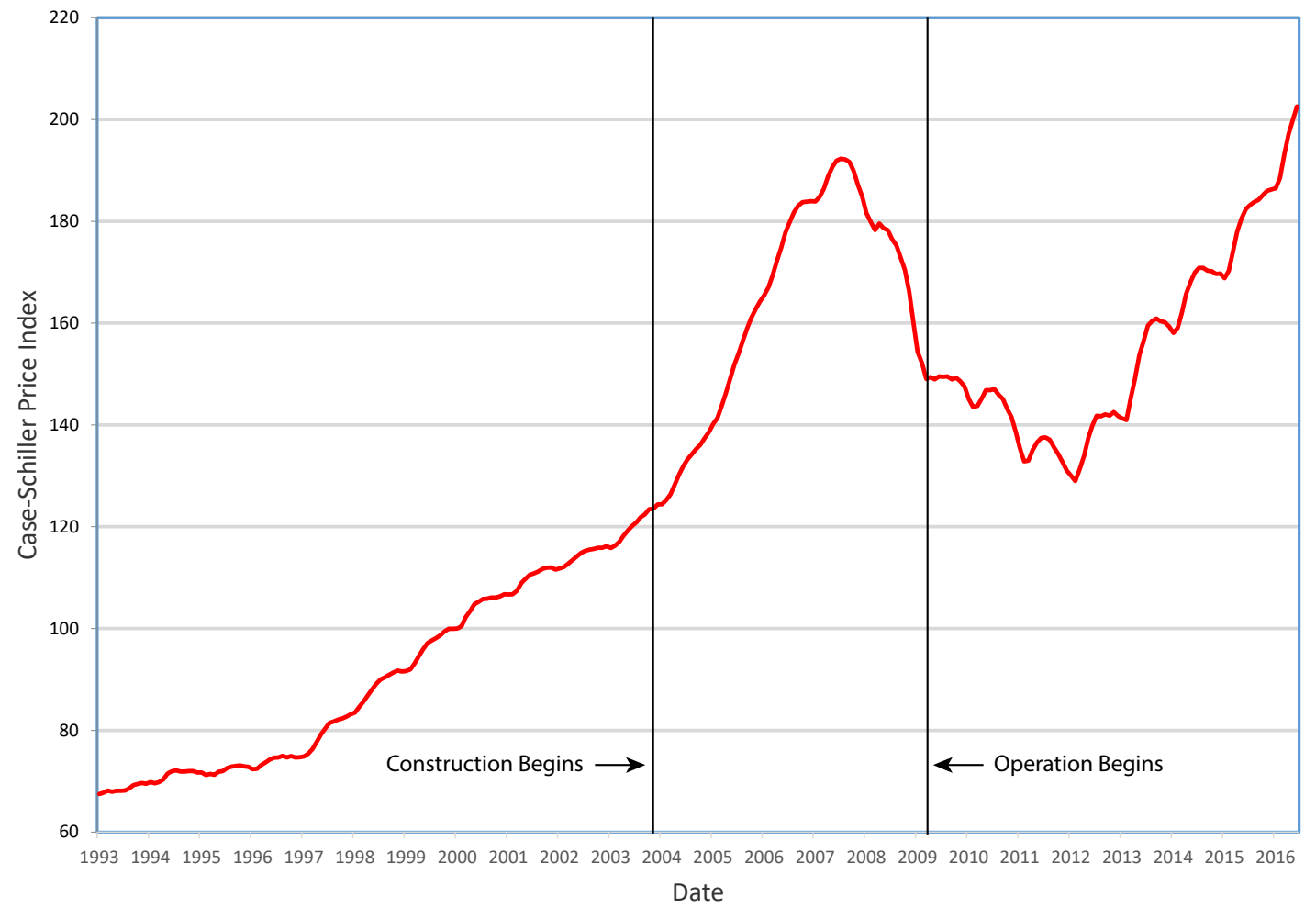

Figure 3: Case-Schiller price index for Seattle metropolitan area. Index value is 100 for January, 2000.

Figure 3 plots of the monthly Case-Schiller price index for the Seattle metro area between January 1992 and March 2016. As is apparent, the Seattle housing market experienced a steep increase in prices between 1992 and 2007. The increase was particularly rapid during the period between 2004 and 2007, part of the so-called "housing bubble" that many cities in the United States experienced during the period. Housing prices peaked in September 2007 then fell precipitously until February 2012. Since the bottom of the trough, prices have rebounded sharply, growing by about 45 percent between 2012 and 2016. Housing prices are now higher than at the peak of the "bubble." The two vertical lines denote November 2003 and February 2009. These are important dates that are used in this analysis, representing roughly the beginning of construction and the initiation of service for the light rail system. 
Table 1: Summary statistics

\begin{tabular}{|c|c|c|c|c|c|c|c|}
\hline Variable & $\begin{array}{l}\text { Sea Tac } \\
\text { Airport }\end{array}$ & $\begin{array}{c}\text { Tukwila } \\
\text { Int'l Blvd }\end{array}$ & $\begin{array}{c}\text { Rainier } \\
\text { Beach }\end{array}$ & Othello & $\begin{array}{c}\text { Columbia } \\
\text { City }\end{array}$ & $\begin{array}{c}\text { Mount } \\
\text { Baker }\end{array}$ & $\begin{array}{c}\text { Beacon } \\
\text { Hill }\end{array}$ \\
\hline Logarithm of & 12.075 & 12.002 & 12.059 & 12.180 & 12.213 & 12.564 & 12.200 \\
\hline $\begin{array}{c}\text { Real Relative } \\
\text { Sale Price }\end{array}$ & $(0.305)$ & $(0.293)$ & $(0.338)$ & $(0.401)$ & $(0.379)$ & $(0.470)$ & $(0.315)$ \\
\hline Sale Price & $\begin{array}{c}223,408 \\
(112,914)\end{array}$ & $\begin{array}{l}206,744 \\
(99,384)\end{array}$ & $\begin{array}{c}224,515 \\
(119,702)\end{array}$ & $\begin{array}{c}268,564 \\
(165,497)\end{array}$ & $\begin{array}{c}270,963 \\
(159,799)\end{array}$ & $\begin{array}{c}394,869 \\
(239,306)\end{array}$ & $\begin{array}{c}261,237 \\
(139,049)\end{array}$ \\
\hline $\begin{array}{c}\text { Number } \\
\text { Bathrooms }\end{array}$ & $\begin{array}{l}1.948 \\
(0.85)\end{array}$ & $\begin{array}{r}1.893 \\
(0.878) \\
\end{array}$ & $\begin{array}{c}1.897 \\
(0.872)\end{array}$ & $\begin{array}{l}1.994 \\
(0.945) \\
\end{array}$ & $\begin{array}{l}1.876 \\
(0.896) \\
\end{array}$ & $\begin{array}{c}2.139 \\
(0.949) \\
\end{array}$ & $\begin{array}{c}1.689 \\
(0.818) \\
\end{array}$ \\
\hline Size $\left(\mathrm{ft}^{2}\right)$ & $\begin{array}{l}1,677 \\
(641) \\
\end{array}$ & $\begin{array}{l}1,670 \\
(669) \\
\end{array}$ & $\begin{array}{l}1,669 \\
(642) \\
\end{array}$ & $\begin{array}{l}1,756 \\
(717) \\
\end{array}$ & $\begin{array}{l}1,652 \\
(636) \\
\end{array}$ & $\begin{array}{l}2,000 \\
(761) \\
\end{array}$ & $\begin{array}{l}1,582 \\
(594) \\
\end{array}$ \\
\hline Age & $\begin{array}{c}39.077 \\
(18.559)\end{array}$ & $\begin{array}{c}43.262 \\
(24.532) \\
\end{array}$ & $\begin{array}{c}48.325 \\
(27.608) \\
\end{array}$ & $\begin{array}{c}50.391 \\
(30.835) \\
\end{array}$ & $\begin{array}{r}57.325 \\
(31.505) \\
\end{array}$ & $\begin{array}{c}65.668 \\
(30.686) \\
\end{array}$ & $\begin{array}{c}67.305 \\
(28.934) \\
\end{array}$ \\
\hline Waterfront Lot & $\begin{array}{c}0.159 \\
(0.366)\end{array}$ & $\begin{array}{c}0.003 \\
(0.055)\end{array}$ & $\begin{array}{c}0.021 \\
(0.144)\end{array}$ & $\begin{array}{c}0.024 \\
(0.154)\end{array}$ & $\begin{array}{c}0.019 \\
(0.137)\end{array}$ & $\begin{array}{c}0.000 \\
--\end{array}$ & $\begin{array}{c}0.000 \\
--\end{array}$ \\
\hline $\begin{array}{c}\text { Outstanding } \\
\text { View }\end{array}$ & $\begin{array}{c}0.070 \\
(0.255)\end{array}$ & $\begin{array}{c}0.058 \\
(0.233)\end{array}$ & $\begin{array}{c}0.161 \\
(0.367)\end{array}$ & $\begin{array}{c}0.142 \\
(0.349)\end{array}$ & $\begin{array}{c}0.152 \\
(0.359)\end{array}$ & $\begin{array}{c}0.301 \\
(0.459)\end{array}$ & $\begin{array}{c}0.120 \\
(0.326)\end{array}$ \\
\hline Lot Size (acres) & $\begin{array}{l}0.241 \\
(0.13) \\
\end{array}$ & $\begin{array}{l}0.253 \\
(0.16) \\
\end{array}$ & $\begin{array}{l}0.174 \\
(0.13) \\
\end{array}$ & $\begin{array}{l}0.146 \\
(0.07)\end{array}$ & $\begin{array}{l}0.125 \\
(0.06)\end{array}$ & $\begin{array}{l}0.114 \\
(0.05) \\
\end{array}$ & $\begin{array}{l}0.106 \\
(0.04) \\
\end{array}$ \\
\hline Size Garage $\left(\mathrm{ft}^{2}\right)$ & $\begin{array}{c}277.80 \\
(256.64)\end{array}$ & $\begin{array}{c}221.11 \\
(251.83)\end{array}$ & $\begin{array}{c}182.80 \\
(220.77)\end{array}$ & $\begin{array}{c}168.15 \\
(211.12)\end{array}$ & $\begin{array}{c}137.64 \\
(192.23)\end{array}$ & $\begin{array}{c}121.01 \\
(175.96)\end{array}$ & $\begin{array}{c}95.49 \\
(155.57)\end{array}$ \\
\hline $\begin{array}{c}\text { Detached } \\
\text { Garage? }\end{array}$ & $\begin{array}{c}0.161 \\
(0.367)\end{array}$ & $\begin{array}{c}0.250 \\
(0.433)\end{array}$ & $\begin{array}{c}0.205 \\
(0.403)\end{array}$ & $\begin{array}{c}0.193 \\
(0.395)\end{array}$ & $\begin{array}{c}0.234 \\
(0.424)\end{array}$ & $\begin{array}{c}0.289 \\
(0.453)\end{array}$ & $\begin{array}{c}0.286 \\
(0.452)\end{array}$ \\
\hline $\begin{array}{c}\text { Close }(<1 / 2 \\
\text { mile })\end{array}$ & $\begin{array}{c}0.042 \\
(0.201)\end{array}$ & $\begin{array}{c}0.103 \\
(0.304)\end{array}$ & $\begin{array}{c}0.177 \\
(0.382)\end{array}$ & $\begin{array}{c}0.293 \\
(0.455)\end{array}$ & $\begin{array}{c}0.211 \\
(0.408)\end{array}$ & $\begin{array}{c}0.416 \\
(0.493)\end{array}$ & $\begin{array}{c}0.554 \\
(0.497)\end{array}$ \\
\hline After 2009 & $\begin{array}{c}0.179 \\
(0.383) \\
\end{array}$ & $\begin{array}{c}0.170 \\
(0.375) \\
\end{array}$ & $\begin{array}{c}0.179 \\
(0.383) \\
\end{array}$ & $\begin{array}{c}0.210 \\
(0.407) \\
\end{array}$ & $\begin{array}{c}0.205 \\
(0.404) \\
\end{array}$ & $\begin{array}{c}0.229 \\
(0.420) \\
\end{array}$ & $\begin{array}{c}0.214 \\
(0.411) \\
\end{array}$ \\
\hline After $\times$ Close & $\begin{array}{c}0.007 \\
(0.082) \\
\end{array}$ & $\begin{array}{c}0.018 \\
(0.134)\end{array}$ & $\begin{array}{c}0.029 \\
(0.169) \\
\end{array}$ & $\begin{array}{c}0.067 \\
(0.251)\end{array}$ & $\begin{array}{c}0.047 \\
(0.212)\end{array}$ & $\begin{array}{c}0.088 \\
(0.283) \\
\end{array}$ & $\begin{array}{c}0.108 \\
(0.311)\end{array}$ \\
\hline
\end{tabular}

Table 1 presents summary statistics for the neighborhoods that are analyzed in this paper. Houses in most of these neighborhoods are generally comparable in terms of sale prices, size, and number of bathrooms. However, homes in the neighborhood around the Mount Baker stations sell for significantly more than those in other neighborhoods, and they are larger. Generally, houses near stations that are further from downtown Seattle are newer, have larger lots, and are less expensive.

Around 20 percent of sales took place after the opening of the light rail line, as indicated by the variable, "After." The mean of the variable "Close" indicates the fraction of houses in the neighborhood that are within the 800-meter catchment basin of the corresponding rail station. In the Mt. Baker and Beacon Hill neighborhoods, a large fraction of houses (roughly half) is close to the station. On the other hand, in the SeaTac and Tukwila areas, only around 5 percent and 10 percent of houses in the neighborhoods fall within the respective catchment areas. This difference has important implications for the analysis. One common approach in this type of analysis is to compare all the "close" houses to all the "distant" houses, combining all stations. In the Seattle case, the comparison would be disproportionately 
between the "close" houses in the Beacon Hill and Mt. Baker neighborhoods with the "distant" houses in the Tukwila and Sea Tac neighborhoods. A comparison of the houses between those two groups is likely to provide a biased estimate of the effect of light rail on housing prices. Thus, I adopt the approach of analyzing each neighborhood separately. This approach is also consistent with the idea that the value of a new transit option in a neighborhood is likely based on the location of that neighborhood relative to employment and commercial centers, existing commuting routes and patterns that naturally differ across neighborhoods, as well as the characteristics of the individuals who choose to live there.

\section{The hedonic pricing model and difference-in-differences estimation}

The hedonic approach is based on an economic theory developed by Rosen (1974). The basic idea, as applied to housing markets, is that housing prices in a neighborhood reflect a general equilibrium in the supply and demand of housing services. In the hedonic model, each of the characteristics of a house provides some benefit, and thus each of these components has a price. Some of these characteristics represent elements of the house itself, such as the size, age, or style of the house. Others represent locational characteristics, such as pleasant views, good neighborhood schools, or convenient access to downtown labor markets. To the extent that a new light rail line provides faster or more comfortable connections to areas of the city that residents want to visit, this should be reflected in housing prices. Those who most value the transit services provided by light rail will be willing to bid more for houses that are close to light rail stations. On the other hand, a rail line may also detract from housing values by creating noise, local traffic, or increasing neighborhood crime. In Seattle, light rail replaces or supplements bus services that were already available in these neighborhoods. It is possible that light rail service is inferior to existing bus services, as explained in Richmond (2001), who discusses how reconfiguring the transit system around a rail line may impose costs on riders.

The vast majority of the work that studies the impact of transit services on housing prices relies on the standard hedonic framework. Most of the work utilizes cross-sectional comparisons, which are likely to lead to bias because of the omission of important variables. The concern in the Seattle case focuses on the characteristics of the station neighborhoods. To the extent that the locations of the stations are different in ways that cannot be measured with available data on housing characteristics, simple cross-sectional comparison of prices will suffer from omitted variable bias. For example, the ability to economically acquire right-of-way for the rail line dictated its exact location. Were the areas thus chosen for stations less desirable that other locations in the neighborhoods that the line serves?

One way to deal with the problem of omitted variables is to use a quasi-experimental approach, such as difference-in-differences estimation. In this case, difference-in-differences compares the changes in housing prices in the areas close to stations (within the catchment area) with other houses in the same neighborhoods that are further away. This is analogous to an experiment-it compares how initiation of rail service affects the price of houses that are well-served by rail (the "experimental group") with houses in the same neighborhoods that are not well-served (the "control group"). This implicitly controls for unobserved characteristics, since the analysis focusses only on changes in the relative prices. In this paper, the analysis follows closely the methods in Pope and Pope (2015) which are discussed in detail in Parmeter and Pope (2012).

I implement the above ideas in a simple regression model that describes the logarithm of the real relative sale price, as follows:

$\ln \left(\mathrm{pi}^{*}\right)=\alpha_{0}+\alpha_{1}$ Close $_{\mathrm{i}}+\alpha_{2}$ After $_{\mathrm{i}}+\alpha_{3}$ Close After $_{\mathrm{i}}+\beta^{\prime} \mathrm{X}_{\mathrm{i}}+\varepsilon_{\mathrm{i}}$

Where pi ${ }^{*}$ represents the real relative price of the house that sold in transaction i. Close is an indi- 
cator that the house involved in the transaction is within 800 meters of the rail station; After indicates that the sale took place after the commencement of rail service; ClosexAfter indicates "close" houses that sold after commencement of rail service. Thus, $\alpha_{3}$ is the "difference-in-differences" estimator-the effect of light rail on housing prices. X represents a vector of other hedonic characteristics that allow us to take account of the fact that houses close to stations might differ in some important characteristics from other houses in the neighborhood. Essentially, this model permits estimation of the effect of light rail by comparing houses that are otherwise identical.

Because the dependent variable is the logarithm of price, the coefficients can be interpreted as proportional changes. Thus, $\alpha_{1}$ is the average proportional difference in price between houses that are close to the station and others in the neighborhood during the period before light rail. For example, the estimate (in Table 2, below) of $\alpha_{1}$ for the Beacon Hill station is 0.038 , meaning that houses that are close to the Beacon Hill station sold for about 3.8 percent more than other houses in the neighborhood, before light rail was available.

\section{$5 \quad$ Estimates}

I estimate two versions of the differences-in-differences model by considering two crucial dates: November 2003, when the financing for the project was finalized and construction began, and December 2009, when operation of the completed "Central Link" between the airport and downtown commenced. Since most of the stations opened in February 2009, but the Sea Tac Airport station opened in December 2009, I use housing sales that took place after December 2009 as the "experimental" group. For the "control" group, I consider sales that took place before January 2004 or before January 2009.

The two time windows allow for possibly different responses to rail service. On the one hand, forward looking property owners may realize that rail service will arrive at some future date, and will take that into account when buying or selling a property, even though the service is not yet available. Furthermore, during the construction period, construction activities may create nuisances that temporarily affect the salability of houses in affected areas. Those nuisances would likely be most concentrated near stations. In this case, the proper comparison is between dates after December 2009 (initiation of service) and before 2004 (when it became clear that the planned system would actually be built). On the other hand, potential owners may not be aware pf the benefits that the rail service provides until they actually experience it. In that case that the relevant comparison is between times when the service is not available (before February 2009), and when it is available (after December 2009).

To simplify the analysis, I use year-end dates to delineate the periods. For the early date, I consider houses that sold before January 2004, even though construction began in November 2003. For the latter date, I consider houses that sold before January 2009, even though service was initiated in February 2009.

In the analyses that follow, reported standard errors are based on heteroscedasticity-robust estimators with clustering to account for the fact that many houses in the sample are sold more than once. (About 38 percent of the broadest sample sold once, 34 percent exactly twice, and 28 percent sold more than twice.) Clustering accounts for the lack of independence between the repeat sales of the same house. 
Table 2: Difference-in-Differences Regression Estimates of Effect of Opening of Light Rail Differences compare years before opening (1992-2008) with those after (2010-2016) (Dependent variable is logarithm of relative real sale price)

\begin{tabular}{|c|c|c|c|c|c|c|c|}
\hline Variable & Beacon Hill & $\begin{array}{l}\text { Mount } \\
\text { Baker }\end{array}$ & $\begin{array}{c}\text { Columbia } \\
\text { City }\end{array}$ & Othello & $\begin{array}{l}\text { Ranier } \\
\text { Beach }\end{array}$ & $\begin{array}{l}\text { Tukwila/ } \\
\text { Intnl Blvd }\end{array}$ & $\begin{array}{l}\text { SeaTac } \\
\text { Airport }\end{array}$ \\
\hline $\begin{array}{l}\text { Close (within } 1 / 2 \\
\text { mile of station) }\end{array}$ & $\begin{array}{l}0.0384^{* *} \\
(0.0136)\end{array}$ & $\begin{array}{c}-0.1298^{* * *} \\
(0.0148)\end{array}$ & $\begin{array}{c}-0.1048^{* * *} \\
(0.0096)\end{array}$ & $\begin{array}{c}-0.0828^{* * *} \\
(0.0095)\end{array}$ & $\begin{array}{l}-0.0031 \\
(0.0085)\end{array}$ & $\begin{array}{l}-0.0106 \\
(0.0096)\end{array}$ & $\begin{array}{l}-0.0222 \\
(0.0154)\end{array}$ \\
\hline $\begin{array}{l}\text { After (sale after } \\
\text { 2009) }\end{array}$ & $\begin{array}{c}0.2031^{* * *} \\
(0.0206)\end{array}$ & $\begin{array}{c}0.1263^{* * *} \\
(0.0175)\end{array}$ & $\begin{array}{c}0.1645^{* * *} \\
(0.0098)\end{array}$ & $\begin{array}{c}0.1199^{* * *} \\
(0.0111)\end{array}$ & $\begin{array}{c}-0.0614^{* * *} \\
(0.0085)\end{array}$ & $\begin{array}{c}-0.1539^{* * *} \\
(0.0077)\end{array}$ & $\begin{array}{c}-0.1051^{* * *} \\
(0.0082)\end{array}$ \\
\hline Close $\mathrm{x}$ After & $\begin{array}{l}-0.0256 \\
(0.0285)\end{array}$ & $\begin{array}{l}-0.0069 \\
(0.0284)\end{array}$ & $\begin{array}{c}0.1019^{* * *} \\
(0.0203)\end{array}$ & $\begin{array}{c}0.0932^{* * *} \\
(0.0196)\end{array}$ & $\begin{array}{l}-0.0116 \\
(0.0203)\end{array}$ & $\begin{array}{l}-0.0060 \\
(0.0226)\end{array}$ & $\begin{array}{c}-0.1347^{* * *} \\
(0.0367)\end{array}$ \\
\hline Baths & $\begin{array}{l}0.0285^{* *} \\
(0.0107)\end{array}$ & $\begin{array}{c}0.0565^{* * *} \\
(0.0091)\end{array}$ & $\begin{array}{l}0.0204^{* *} \\
(0.0064)\end{array}$ & $\begin{array}{c}0.0347^{* * *} \\
(0.0067)\end{array}$ & $\begin{array}{c}0.0241^{* * *} \\
(0.0055\end{array}$ & $\begin{array}{c}0.0185^{* * *} \\
(0.0053)\end{array}$ & $\begin{array}{c}0.0192^{* * *} \\
(0.0057)\end{array}$ \\
\hline Size $\left(\mathrm{ft}^{2}\right)$ & $\begin{array}{c}0.00035^{* * *} \\
(0.00004)\end{array}$ & $\begin{array}{c}0.00048^{* * *} \\
(0.00002)\end{array}$ & $\begin{array}{c}0.00030^{* * *} \\
(0.00002)\end{array}$ & $\begin{array}{c}0.00031^{* * *} \\
(0.00002)\end{array}$ & $\begin{array}{c}0.000431^{* * *} \\
(0.000020)\end{array}$ & $\begin{array}{c}0.00030^{* * *} \\
(0.00002)\end{array}$ & $\begin{array}{c}0.00031^{* * *} \\
(0.00002)\end{array}$ \\
\hline $\mathrm{Size}^{2}$ & $\begin{array}{c}-5.23 \mathrm{e}-08^{* * *} \\
(1.15 \mathrm{e}-08)\end{array}$ & $\begin{array}{c}-3.44 \mathrm{e}-08^{* * *} \\
(3.17 \mathrm{e}-09)\end{array}$ & $\begin{array}{c}2.03 \mathrm{e}-08^{* * *} \\
(5.53 \mathrm{e}-09)\end{array}$ & $\begin{array}{c}-15 \mathrm{e}-08^{* * *} \\
(2.77 \mathrm{e}-09)\end{array}$ & $\begin{array}{c}-5.10 \mathrm{e}-08^{* * *} \\
(4.76 \mathrm{e}-09)\end{array}$ & $\begin{array}{c}-2.37 \mathrm{e}-08^{* * * *} \\
(3.13 \mathrm{e}-09)\end{array}$ & $\begin{array}{c}-1.94 \mathrm{e}-08^{* * *} \\
(3.68 \mathrm{e}-09)\end{array}$ \\
\hline Age & $\begin{array}{c}-0.00593^{* * *} \\
(0.000890)\end{array}$ & $\begin{array}{l}-0.00213^{* *} \\
(0.000821)\end{array}$ & $\begin{array}{c}-0.00509^{* * *} \\
(0.000474)\end{array}$ & $\begin{array}{c}-0.00484^{* * *} \\
(0.000497)\end{array}$ & $\begin{array}{c}-0.004017^{* * *} \\
(0.000390)\end{array}$ & $\begin{array}{c}-0.006067^{* * *} \\
(0.000376)\end{array}$ & $\begin{array}{c}-0.006522^{* * *} \\
(0.000495)\end{array}$ \\
\hline $\mathrm{Age}^{2}$ & $\begin{array}{c}.00 \mathrm{e}-05^{* * *} \\
(7.49 \mathrm{e}-06)\end{array}$ & $\begin{array}{c}3.40 \mathrm{e}-05^{* * *} \\
(7.43 \mathrm{e}-06)\end{array}$ & $\begin{array}{c}4.25 \mathrm{e}-05^{* * *} \\
(4.07 \mathrm{e}-06)\end{array}$ & $\begin{array}{c}3.81 \mathrm{e}-05^{* * *} \\
(4.36 \mathrm{e}-06)\end{array}$ & $\begin{array}{c}3.56 \mathrm{e}-05^{* * *} \\
(3.48 \mathrm{e}-06)\end{array}$ & $\begin{array}{c}3.86 \mathrm{e}-05^{* * *} \\
(3.79 \mathrm{e}-06)\end{array}$ & $\begin{array}{c}4.83 \mathrm{e}-05^{* * *} \\
(6.92 \mathrm{e}-06)\end{array}$ \\
\hline Waterfront & - & $\begin{array}{c}0.6723^{* * *} \\
(0.0712)\end{array}$ & $\begin{array}{c}0.2902^{* * *} \\
(0.0253)\end{array}$ & $\begin{array}{c}0.2269^{* * *} \\
(0.0234)\end{array}$ & $\begin{array}{c}0.4724^{* * *} \\
(0.0201)\end{array}$ & $\begin{array}{c}0.0372 \\
(0.0498)\end{array}$ & $\begin{array}{c}0.0584^{* * *} \\
(0.0077)\end{array}$ \\
\hline View & $\begin{array}{l}0.0509^{* *} \\
(0.0181)\end{array}$ & $\begin{array}{c}0.1599^{* * *} \\
(0.0142)\end{array}$ & $\begin{array}{c}0.2325^{\text {*** }} \\
(0.0103)\end{array}$ & $\begin{array}{c}0.2869^{* * *} \\
(0.0124)\end{array}$ & $\begin{array}{c}0.2198^{* * *} \\
(0.0087)\end{array}$ & $\begin{array}{c}0.0611^{\text {*** }} \\
(0.0119)\end{array}$ & $\begin{array}{c}0.1484^{* * *} \\
(0.0112)\end{array}$ \\
\hline Lot (acres) & $\begin{array}{l}0.0509^{* *} \\
(0.0181)\end{array}$ & $\begin{array}{c}1.3753^{* * *} \\
(0.1827)\end{array}$ & $\begin{array}{c}0.8103^{* * *} \\
(0.0983)\end{array}$ & $\begin{array}{c}0.8986^{* * *} \\
(0.0824)\end{array}$ & $\begin{array}{l}-0.0818^{*} \\
(0.0355)\end{array}$ & $\begin{array}{c}0.2000^{* * *} \\
(0.0267)\end{array}$ & $\begin{array}{c}0.5928^{* * *} \\
(0.0494)\end{array}$ \\
\hline $\operatorname{Lot}^{2}$ & $\begin{array}{c}3.0950 \\
(1.8734)\end{array}$ & $\begin{array}{c}-0.8996^{* * *} \\
(0.1645)\end{array}$ & $\begin{array}{c}-0.2619^{* *} \\
(0.0904)\end{array}$ & $\begin{array}{l}-0.1283^{*} \\
(0.0597)\end{array}$ & $\begin{array}{l}0.0322^{* *} \\
(0.0099)\end{array}$ & $\begin{array}{l}-0.0064 \\
(0.0114) \\
\end{array}$ & $\begin{array}{c}-0.2006^{* * *} \\
(0.0319) \\
\end{array}$ \\
\hline Garage (sf) & $\begin{array}{c}0.00033^{* * *} \\
(0.00005)\end{array}$ & $\begin{array}{l}0.00022^{* * *} \\
(0.000045)\end{array}$ & $\begin{array}{c}0.00021^{* * *} \\
(0.00003)\end{array}$ & $\begin{array}{c}0.00020^{* * *} \\
(0.00002)\end{array}$ & $\begin{array}{c}0.000193^{* * *} \\
(0.000018)\end{array}$ & $\begin{array}{c}0.000171^{* * *} \\
(0.000014)\end{array}$ & $\begin{array}{c}0.000172^{* * *} \\
(0.000014)\end{array}$ \\
\hline $\begin{array}{l}\text { Detached } \\
\text { Garage }\end{array}$ & $\begin{array}{c}0.0775^{* * *} \\
(0.0140)\end{array}$ & $\begin{array}{c}0.1413^{* * *} \\
(0.0149)\end{array}$ & $\begin{array}{c}0.0701^{* * *} \\
(0.0087)\end{array}$ & $\begin{array}{c}0.0420^{* * *} \\
(0.0102)\end{array}$ & $\begin{array}{c}0.0784^{* * *} \\
(0.0079)\end{array}$ & $\begin{array}{c}0.0480^{* * *} \\
(0.0069)\end{array}$ & $\begin{array}{c}0.0730^{* * *} \\
(0.0085)\end{array}$ \\
\hline Constant & $\begin{array}{c}11.7027^{* * *} \\
(0.0537)\end{array}$ & $\begin{array}{c}11.3914^{* * *} \\
(0.0366)\end{array}$ & $\begin{array}{c}11.6696^{* * *} \\
(0.0278)\end{array}$ & $\begin{array}{c}11.5490^{* * *} \\
(0.0244)\end{array}$ & $\begin{array}{c}11.4713^{* * *} \\
(0.0236)\end{array}$ & $\begin{array}{c}11.6384^{* * *} \\
(0.0195)\end{array}$ & $\begin{array}{c}11.5527^{* * *} \\
(0.0210)\end{array}$ \\
\hline $\mathrm{R}^{2}$ & 0.38 & 0.69 & 0.52 & 0.66 & 0.57 & 0.63 & 0.70 \\
\hline $\mathrm{N}$ & 1,851 & 2,871 & 6,015 & 4,506 & 5,921 & 4,673 & 3,817 \\
\hline
\end{tabular}

Notes: ${ }^{*} \mathrm{p}<0.05{ }^{* *} \mathrm{p}<0.01 ;{ }^{* * *} \mathrm{p}<0.001$

Table 2 presents estimates of the latter comparison. That is, it compares sales that took place after December 2009 relative to those that took place before January 2009. This table reports an estimate of the proximate effect of light rail service without considering the possible forward-looking responses to the announcement of the system by buyers and sellers. The hedonic variables included are: number of bathrooms, size of the house and its square (in square feet), age of the house and its square (in years), acreage of lot and its square, size of garage (in square feet), if the garage is detached, whether the lot is located on a waterfront, and whether the lot has outstanding views.

The coefficient on Close indicates the relative value of parcels close to stations before 2009. Thus, except for the Beacon Hill catchment area, houses close to light rail stations sold at a discount compared 
houses further away. In some cases, these estimated differences are large and statistically significant. For example, in the Mt. Baker neighborhood, houses close the eventual location of the rail station sold for 13 percent less than houses further away, on average.

The coefficient on After indicates the relative growth rate of houses in the analysis neighborhoods, compared to houses in the Seattle metro area generally. (Recall that the dependent variable is the logarithm of the sale price of a house deflated by the metro-wide Case-Schiller price index.) These estimates indicate that relative to prices in all of Seattle, housing prices have increased more rapidly in the analysis neighborhoods that are closer to downtown Seattle-Othello, Columbia City, Mt. Baker, and Beacon Hill. Generally, the increase has been larger for neighborhoods that are closer to downtown. For neighborhoods that are most distant from downtown, the relative prices have fallen.

The crucial coefficient for the analysis is the interaction variable-ClosexAfter. This shows how housing prices changed with the opening of the rail system, compared to the changes of prices for houses in the same neighborhood that are more distant from the stations. For all but one of the neighborhoods, the estimate of the effect of light rail is negative. For Sea Tac and Othello, these changes are also statistically significantly different from zero. However, for the Columbia City neighborhood, the estimated impact of the initiation of rail service is positive, quite large, and statistically significant. 
Table 3: Difference-in-Differences Regression Estimates Difference compares years before construction (1992-2003) with those after opening (2010-2016) (Dependent variable is logarithm of relative real sale price)

\begin{tabular}{|c|c|c|c|c|c|c|c|}
\hline Variable & Beacon & $\begin{array}{l}\text { Mount } \\
\text { Baker }\end{array}$ & $\begin{array}{c}\text { Columbia } \\
\text { City }\end{array}$ & Othello & $\begin{array}{l}\text { Ranier } \\
\text { Beach }\end{array}$ & $\begin{array}{l}\text { Tukwila/ } \\
\text { Intnl Blvd }\end{array}$ & $\begin{array}{l}\text { SeaTac } \\
\text { Airport }\end{array}$ \\
\hline Close & $\begin{array}{l}0.0394^{*} \\
(0.0159)\end{array}$ & $\begin{array}{c}-0.1449^{* * *} \\
(0.0174)\end{array}$ & $\begin{array}{c}-0.1234^{* * *} \\
(0.0113)\end{array}$ & $\begin{array}{c}-0.0907^{* * *} \\
(0.0119)\end{array}$ & $\begin{array}{l}-0.0098 \\
(0.0104)\end{array}$ & $\begin{array}{l}-0.0050 \\
(0.0119)\end{array}$ & $\begin{array}{l}-0.0206 \\
(0.0182)\end{array}$ \\
\hline After & $\begin{array}{c}0.2474^{* * *} \\
(0.0217)\end{array}$ & $\begin{array}{c}0.1514^{* * *} \\
(0.0187)\end{array}$ & $\begin{array}{c}0.2074^{* * *} \\
(0.0103)\end{array}$ & $\begin{array}{c}0.1696^{* * *} \\
(0.0120)\end{array}$ & $\begin{array}{c}-0.0273^{* *} \\
(0.0092)\end{array}$ & $\begin{array}{c}-0.1298^{* * *} \\
(0.0084)\end{array}$ & $\begin{array}{c}-0.0985^{* * *} \\
(0.0092)\end{array}$ \\
\hline Close $\mathrm{x}$ After & $\begin{array}{l}-0.0217 \\
(0.0297)\end{array}$ & $\begin{array}{c}0.0042 \\
(0.0297)\end{array}$ & $\begin{array}{c}0.1183^{* * *} \\
(0.0213)\end{array}$ & $\begin{array}{c}-0.0883^{* * *} \\
(0.0211)\end{array}$ & $\begin{array}{l}-0.0079 \\
(0.0215)\end{array}$ & $\begin{array}{l}-0.0101 \\
(0.0243)\end{array}$ & $\begin{array}{c}-0.1330^{* * *} \\
(0.0384)\end{array}$ \\
\hline Baths & $\begin{array}{l}0.0282^{*} \\
(0.0121) \\
\end{array}$ & $\begin{array}{c}0.0578^{* * *} \\
(0.0101)\end{array}$ & $\begin{array}{l}0.0154^{*} \\
(0.0072)\end{array}$ & $\begin{array}{c}0.0272^{* * *} \\
(0.0078)\end{array}$ & $\begin{array}{l}0.0198^{* *} \\
(0.0065)\end{array}$ & $\begin{array}{c}0.0088 \\
(0.0063)\end{array}$ & $\begin{array}{l}0.0193^{* *} \\
(0.0067)\end{array}$ \\
\hline Size $\left(\mathrm{ft}^{2}\right)$ & $\begin{array}{c}0.000352^{* * *} \\
(0.000050) \\
\end{array}$ & $\begin{array}{c}0.000483^{* * *} \\
(0.000024) \\
\end{array}$ & $\begin{array}{c}0.000322^{* * *} \\
(0.000026)\end{array}$ & $\begin{array}{c}0.000307^{* * *} \\
(0.000017) \\
\end{array}$ & $\begin{array}{c}0.000447^{* * *} \\
(0.000023)\end{array}$ & $\begin{array}{c}0.000323^{* * *} \\
(0.000017) \\
\end{array}$ & $\begin{array}{c}0.000297^{* * *} \\
(0.000021)\end{array}$ \\
\hline Size2 & $\begin{array}{c}-5.52 \mathrm{e}-08^{* * *} \\
(1.33 \mathrm{e}-08)\end{array}$ & $\begin{array}{c}-3.58 \mathrm{e}-08^{* * *} \\
(3.73 \mathrm{e}-09)\end{array}$ & $\begin{array}{c}-2.60 \mathrm{e}-08^{* * *} \\
(6.23 \mathrm{e}-09)\end{array}$ & $\begin{array}{c}-2.09 \mathrm{e}-08^{* * *} \\
(3.03 \mathrm{e}-09)\end{array}$ & $\begin{array}{c}-5.38 \mathrm{e}-08^{* * *} \\
(5.60 \mathrm{e}-09)\end{array}$ & $\begin{array}{c}-2.92 \mathrm{e}-08^{* * *} \\
(3.68 \mathrm{e}-09)\end{array}$ & $\begin{array}{c}-1.34 \mathrm{e}-08^{* *} \\
(4.59 \mathrm{e}-09)\end{array}$ \\
\hline Age & $\begin{array}{c}-0.005313^{* * *} \\
(0.001009) \\
\end{array}$ & $\begin{array}{c}-0.001945^{*} \\
(0.000932) \\
\end{array}$ & $\begin{array}{c}-0.004767^{* * *} \\
(0.000535) \\
\end{array}$ & $\begin{array}{c}-0.004454^{* * *} \\
(0.000592) \\
\end{array}$ & $\begin{array}{c}-0.004380^{* * *} \\
(0.000465) \\
\end{array}$ & $\begin{array}{c}-0.006907^{* * *} \\
(0.000462) \\
\end{array}$ & $\begin{array}{c}-0.006782^{* * *} \\
(0.000571)\end{array}$ \\
\hline Age2 & $\begin{array}{c}4.16 \mathrm{e}-05^{* * *} \\
(8.55 \mathrm{e}-06)\end{array}$ & $\begin{array}{c}3.22 \mathrm{e}-05^{* * *} \\
(8.50 \mathrm{e}-06)\end{array}$ & $\begin{array}{c}3.55 \mathrm{e}-05^{* * *} \\
(4.62 \mathrm{e}-06)\end{array}$ & $\begin{array}{c}3.02 \mathrm{e}-05^{* * *} \\
(5.18 \mathrm{e}-06)\end{array}$ & $\begin{array}{c}3.43 e-05^{* * *} \\
(4.17 e-06)\end{array}$ & $\begin{array}{c}4.13 \mathrm{e}-05^{* * *} \\
(4.66 \mathrm{e}-06)\end{array}$ & $\begin{array}{c}4.74 \mathrm{e}-05^{* * *} \\
(7.97 \mathrm{e}-06)\end{array}$ \\
\hline Waterfront & -- & $\begin{array}{c}0.6472^{* * *} \\
(0.0771)\end{array}$ & $\begin{array}{c}0.2623^{* * *} \\
(0.0283)\end{array}$ & $\begin{array}{c}0.2040^{* * *} \\
(0.0276)\end{array}$ & $\begin{array}{c}0.4644^{* * *} \\
(0.0227)\end{array}$ & $\begin{array}{c}0.0394 \\
(0.0584)\end{array}$ & $\begin{array}{c}0.0471^{* * *} \\
(0.0091)\end{array}$ \\
\hline View & $\begin{array}{l}0.0611^{* *} \\
(0.0200)\end{array}$ & $\begin{array}{c}0.1537^{* * *} \\
(0.0162)\end{array}$ & $\begin{array}{c}0.2521^{* * *} \\
(0.0115)\end{array}$ & $\begin{array}{c}0.2952^{* * *} \\
(0.0145)\end{array}$ & $\begin{array}{c}0.2219^{* * *} \\
(0.0102)\end{array}$ & $\begin{array}{c}0.0620^{* * *} \\
(0.0144)\end{array}$ & $\begin{array}{c}0.1446^{* * *} \\
(0.0130)\end{array}$ \\
\hline Lot (acres) & $\begin{array}{c}0.5880 \\
(0.6628)\end{array}$ & $\begin{array}{c}1.4153^{* * *} \\
(0.2061)\end{array}$ & $\begin{array}{c}0.8670^{* * *} \\
(0.1091)\end{array}$ & $\begin{array}{c}0.9429^{* * *} \\
(0.0931)\end{array}$ & $\begin{array}{l}-0.0913^{*} \\
(0.0417)\end{array}$ & $\begin{array}{c}0.2292^{* * *} \\
(0.0313)\end{array}$ & $\begin{array}{c}0.5780^{* * *} \\
(0.0567)\end{array}$ \\
\hline Lot2 & $\begin{array}{c}1.4301 \\
(2.4902) \\
\end{array}$ & $\begin{array}{c}-0.9184^{* * *} \\
(0.1765)\end{array}$ & $\begin{array}{c}-0.2835^{* *} \\
(0.0937)\end{array}$ & $\begin{array}{l}-0.1501^{*} \\
(0.0636) \\
\end{array}$ & $\begin{array}{l}0.0345^{* *} \\
(0.0108)\end{array}$ & $\begin{array}{l}-0.0061 \\
(0.0123)\end{array}$ & $\begin{array}{c}-0.2115^{* * *} \\
(0.0349)\end{array}$ \\
\hline Garage (sf) & $\begin{array}{c}0.000354^{* * *} \\
(0.000052)\end{array}$ & $\begin{array}{c}0.000235^{* * *} \\
(0.000051)\end{array}$ & $\begin{array}{c}0.000214^{* * *} \\
(0.000028)\end{array}$ & $\begin{array}{c}0.000223^{* * *} \\
(0.000028)\end{array}$ & $\begin{array}{c}0.000200^{* * *} \\
(0.000021)\end{array}$ & $\begin{array}{c}0.000165^{\text {**** }} \\
(0.000017)\end{array}$ & $\begin{array}{c}0.000191^{\text {*** }} \\
(0.000016)\end{array}$ \\
\hline $\begin{array}{l}\text { Detached } \\
\text { Garage }\end{array}$ & $\begin{array}{c}0.0829^{* * *} \\
(0.0156)\end{array}$ & $\begin{array}{c}0.1489^{* * *} \\
(0.0168)\end{array}$ & $\begin{array}{c}0.0660^{* * *} \\
(0.0099)\end{array}$ & $\begin{array}{c}0.0415^{* * *} \\
(0.0120)\end{array}$ & $\begin{array}{c}0.0823^{* * *} \\
(0.0092)\end{array}$ & $\begin{array}{c}0.0452^{* * *} \\
(0.0082)\end{array}$ & $\begin{array}{c}0.0729^{* * *} \\
(0.0100)\end{array}$ \\
\hline Constant & $\begin{array}{c}11.6382^{* * *} \\
(0.0636)\end{array}$ & $\begin{array}{c}11.3575^{* * *} \\
(0.0420)\end{array}$ & $\begin{array}{c}11.6148^{* * *} \\
(0.0315)\end{array}$ & $\begin{array}{c}11.5228^{* * *} \\
(0.0282)\end{array}$ & $\begin{array}{c}11.4539^{* * *} \\
(0.0278)\end{array}$ & $\begin{array}{c}11.6385^{* * *} \\
(0.0233)\end{array}$ & $\begin{array}{c}11.5705^{* * *} \\
(0.0249)\end{array}$ \\
\hline $\mathrm{R}^{2}$ & 0.42 & 0.70 & 0.55 & 0.67 & 0.57 & 0.61 & 0.70 \\
\hline $\mathrm{N}$ & 1,451 & 2,264 & 4,697 & 3,356 & 4,454 & 3,484 & 2,905 \\
\hline
\end{tabular}

Notes: ${ }^{*} \mathrm{p}<0.05{ }^{* *} \mathrm{p}<0.01 ;{ }^{* * *} \mathrm{p}<0.001$

Table 3 reports estimates using the earlier date window, comparing sales before January 2004 with those that took place after December 2009. The estimates from this analysis are very similar, both qualitatively and quantitatively, to the previous analysis reported in Table 2 . In this case, the sample sizes are somewhat smaller, since the analysis excludes sales that took place between January 2004 and December 2009.

As a test for sensitivity, I have also examined slightly different time periods. For example, I have estimated the model comparing the period between 2003 and 2007 with the period from 2011 through 2015, as well as comparing the period from 1999-2003 with the period from 2011-2015. Results are qualitatively very similar. Thus, the results to not appear to be sensitive to the particular definitions of "before" and "after." 


\section{$6 \quad$ Residual analysis}

An important underlying assumption for the analysis is that light rail stations are not sited in areas for which there may have been preexisting trends in housing prices. Although I do not expect this to be the case, it is possible to examine the question graphically. To do this, I estimate for each of the neighborhoods a hedonic price regression model but leave out the indicators for the timing of the light rail, and the location of the house relative to the rail station. Thus, the residuals from these regressions "contain" the effects that are emphasized in the analysis. I then average these residuals for each year, separately for the "close" houses and the "not close" houses.


Figure 4: Residual analysis by station neighborhoods. 
These results are presented in the different panels of Figure 4. In each figure the dashed line represents houses that are within the $1 / 2$-mile radius of the station, while the solid line represents the average residual for houses that are within 2 miles but more than 0.5 mile from the station. Generally, the two lines are roughly parallel. For example, for the Beacon Hill neighborhood, the dashed line is slightly above the solid line, indicating that houses near the eventual location of the station carried a small premium relative to other houses in the neighborhood. After the opening of the light rail station, this premium has disappeared, but the two lines continue to track very closely. The upward trend in both lines, apparent in the top four figures, indicates that the price of houses in these neighborhoods has generally increased more rapidly than the average house in the Seattle metro area. For houses near the Othello station, the two lines dramatically diverge after the opening of the light rail. On the other hand, for Columbia City, the rather large discount that was present in the 1990s and the 2000s for houses close to the eventual location of the rail station disappears after the opening of light rail.

These figures basically show graphically what the regression estimates report. However, they also show that the existing trends of housing prices in both the "close" and "far" parts of these neighborhoods generally tracked each other quite closely until 2009. Thus, they lend credence to a causal interpretation of the difference-in-differences estimators.

\section{$7 \quad$ Housing composition effects}

In this study, I interpret the difference-in-differences estimates to represent changes in homebuyers' willingness to pay for rail transit service. However, it is possible that there is also a housing supply response. That is, the composition of the housing around stations may change in response to the availability of light rail service. For example, the presence of rail service might lead to denser housing, or different types of housing that appeal to homebuyers of different income groups. Such a compositional change would, at least, muddy the interpretation that observed price changes reflect consumers' willingness to pay for new transit services.

I address this question with two analyses. First, I re-estimate the difference-in-differences regression models but restrict the sample to housing that was built before 2004. Thus, the new sample consists of the housing stock that existed before it was known that light rail would be built in these neighborhoods. The composition of this sample could not have been affected light rail.

The results based on this pre-rail sample are presented in Appendix Tables 1 and 2, corresponding to Tables 2 and 3, above. The estimates of the crucial coefficients are almost identical for all the station neighborhoods, except for Columbia City. For Columbia City, the coefficients fall by more than half-from 10.2 percent (in Table 2) to 4.6 percent (in Appendix Table 1). (The estimated effect is still statistically significantly different from zero.) This analysis supports the interpretation that the original estimated effects represent legitimate differences in willingness to pay, although the results for Columbia City should be considered with some suspicion.

The second analysis examines directly the composition of housing. In this analysis, I estimate a set of regression models where the dependent variable is some housing characteristic, and the independent variables are the proximity, timing, and interaction indicators. The results are reported in Table 4 for the samples that correspond to the pre-2009/post-2009 comparison. Panel A shows the results for the size of the house (in square feet). Again, the crucial variable is the close/after interaction. For all stations, the difference-in-differences estimates are not statistically significantly different from zero, although the point estimates are moderately large for Beacon Hill and SeaTac neighborhoods. 
Table 4: Impact of Light Rail Opening on Characteristics of Houses Sold

\begin{tabular}{|c|c|c|c|c|c|c|c|}
\hline Variables & $\begin{array}{c}\text { Beacon } \\
\text { Hill } \\
\end{array}$ & $\begin{array}{l}\text { Mount } \\
\text { Baker }\end{array}$ & $\begin{array}{c}\text { Columbia } \\
\text { City }\end{array}$ & Othello & $\begin{array}{c}\text { Rainier } \\
\text { Beach }\end{array}$ & $\begin{array}{l}\text { Tukwila/ } \\
\text { Intnl Blvd }\end{array}$ & $\begin{array}{l}\text { SeaTac } \\
\text { Airport }\end{array}$ \\
\hline \multicolumn{8}{|c|}{ Panel A: Size $\left(\mathrm{ft}^{2}\right)$} \\
\hline Close & $\begin{array}{c}46.57 \\
(40.64) \\
\end{array}$ & $\begin{array}{c}-492.6^{* * *} \\
(50.99)\end{array}$ & $\begin{array}{c}15.76 \\
(30.98) \\
\end{array}$ & $\begin{array}{c}-144.0^{* * *} \\
(32.10)\end{array}$ & $\begin{array}{l}-1.856 \\
(31.52) \\
\end{array}$ & $\begin{array}{l}-21.10 \\
(39.78) \\
\end{array}$ & $\begin{array}{c}-511.7^{* * *} \\
(44.40)\end{array}$ \\
\hline After & $\begin{array}{c}49.18 \\
(53.28) \\
\end{array}$ & $\begin{array}{c}165.2^{* * *} \\
(54.23)\end{array}$ & $\begin{array}{c}120.2^{* * *} \\
(23.36)\end{array}$ & $\begin{array}{c}198.2^{* * * *} \\
(39.96)\end{array}$ & $\begin{array}{c}101.2^{* * * *} \\
(23.82)\end{array}$ & $\begin{array}{c}128.4^{* * *} \\
(30.67) \\
\end{array}$ & $\begin{array}{c}79.87^{* * *} \\
(29.08)\end{array}$ \\
\hline Close $\mathrm{x}$ After & $\begin{array}{c}105.6 \\
(72.24) \\
\end{array}$ & $\begin{array}{l}-6.211 \\
(73.89) \\
\end{array}$ & $\begin{array}{l}-2.105 \\
(45.06) \\
\end{array}$ & $\begin{array}{l}-72.64 \\
(55.37) \\
\end{array}$ & $\begin{array}{c}9.026 \\
(61.70) \\
\end{array}$ & $\begin{array}{c}19.14 \\
(89.35) \\
\end{array}$ & $\begin{array}{c}213.6 \\
(137.6) \\
\end{array}$ \\
\hline Constant & $\begin{array}{c}1,535^{* * *} \\
(30.28)\end{array}$ & $\begin{array}{c}2,315^{* * *} \\
(38.88)\end{array}$ & $\begin{array}{c}1,636^{* * *} \\
(14.16)\end{array}$ & $\begin{array}{c}1,788^{* * *} \\
(20.22)\end{array}$ & $\begin{array}{c}1,659^{* * *} \\
(13.61)\end{array}$ & $\begin{array}{c}1,652^{* * *} \\
(14.52)\end{array}$ & $\begin{array}{c}1,687^{* * *} \\
(14.87)\end{array}$ \\
\hline Observations & 1,846 & 2,868 & 6,010 & 4,499 & 5,903 & 4,660 & 3,815 \\
\hline R-squared & 0.009 & 0.068 & 0.006 & 0.018 & 0.004 & 0.005 & 0.025 \\
\hline \multicolumn{8}{|c|}{ Panel B: Lot Size (Acres) } \\
\hline Close & $\begin{array}{c}-0.00540^{* *} \\
(0.00233)\end{array}$ & $\begin{array}{c}-0.0132^{* * *} \\
(0.00277)\end{array}$ & $\begin{array}{l}-0.00161 \\
(0.00291)\end{array}$ & $\begin{array}{c}-0.0171^{* * *} \\
(0.00295)\end{array}$ & $\begin{array}{c}-0.0352^{* * *} \\
(0.00354)\end{array}$ & $\begin{array}{c}0.0110 \\
(0.00956)\end{array}$ & $\begin{array}{c}-0.0277^{* * *} \\
(0.00441)\end{array}$ \\
\hline After & $\begin{array}{c}-0.00817^{* *} \\
(0.00340)\end{array}$ & $\begin{array}{c}0.00364 \\
(0.00437)\end{array}$ & $\begin{array}{c}0.00115 \\
(0.00248)\end{array}$ & $\begin{array}{c}0.0117^{* *} \\
(0.00558)\end{array}$ & $\begin{array}{c}0.00415 \\
(0.00505)\end{array}$ & $\begin{array}{c}0.00599 \\
(0.00665)\end{array}$ & $\begin{array}{c}0.00684 \\
(0.00674)\end{array}$ \\
\hline Close $\mathrm{x}$ After & $\begin{array}{l}0.0105^{* *} \\
(0.00432)\end{array}$ & $\begin{array}{c}0.00491 \\
(0.00812)\end{array}$ & $\begin{array}{c}-0.0164^{* * *} \\
(0.00464)\end{array}$ & $\begin{array}{l}-0.0151^{* *} \\
(0.00666)\end{array}$ & $\begin{array}{c}0.00212 \\
(0.00723)\end{array}$ & $\begin{array}{l}0.00977 \\
(0.0205)\end{array}$ & $\begin{array}{c}0.0118 \\
(0.0149)\end{array}$ \\
\hline Constant & $\begin{array}{l}0.110^{* * *} \\
(0.00188)\end{array}$ & $\begin{array}{l}0.126^{* * *} \\
(0.00229)\end{array}$ & $\begin{array}{c}0.126^{* * *} \\
(0.000976)\end{array}$ & $\begin{array}{c}0.153^{* * *} \\
(0.00217)\end{array}$ & $\begin{array}{c}0.179^{* * *} \\
(0.00247)\end{array}$ & $\begin{array}{c}0.251^{* * *} \\
(0.00349)\end{array}$ & $\begin{array}{c}0.242^{* * *} \\
(0.00291)\end{array}$ \\
\hline Observations & 1,846 & 2,868 & 6,010 & 4,499 & 5,903 & 4,660 & 3,815 \\
\hline R-squared & 0.007 & 0.009 & 0.004 & 0.012 & 0.011 & 0.001 & 0.002 \\
\hline \multicolumn{8}{|c|}{ Panel C: Age } \\
\hline Close & $\begin{array}{c}8.644^{* * *} \\
(1.948)\end{array}$ & $\begin{array}{c}6.734^{* * *} \\
(1.627)\end{array}$ & $\begin{array}{c}-3.293^{* *} \\
(1.533)\end{array}$ & $\begin{array}{c}-6.230^{* * *} \\
(1.479)\end{array}$ & $\begin{array}{c}-7.467^{* * *} \\
(1.398)\end{array}$ & $\begin{array}{c}0.593 \\
(1.465) \\
\end{array}$ & $\begin{array}{c}14.34^{* * *} \\
(1.085)\end{array}$ \\
\hline After & $\begin{array}{l}-4.235 \\
(3.250)\end{array}$ & $\begin{array}{c}5.476^{* * *} \\
(1.880)\end{array}$ & $\begin{array}{c}6.416^{* * *} \\
(1.194)\end{array}$ & $\begin{array}{c}9.457^{* * *} \\
(1.358)\end{array}$ & $\begin{array}{c}11.53^{* * *} \\
(1.004)\end{array}$ & $\begin{array}{c}8.939^{* * *} \\
(1.131)\end{array}$ & $\begin{array}{c}11.37^{* * *} \\
(0.855)\end{array}$ \\
\hline Close $\mathrm{x}$ After & $\begin{array}{c}12.26^{* * *} \\
(3.856)\end{array}$ & $\begin{array}{c}2.863 \\
(2.758) \\
\end{array}$ & $\begin{array}{c}-14.78^{* * *} \\
(2.880)\end{array}$ & $\begin{array}{c}-5.728^{* *} \\
(2.612)\end{array}$ & $\begin{array}{c}1.595 \\
(2.753) \\
\end{array}$ & $\begin{array}{c}3.618 \\
(2.940)\end{array}$ & $\begin{array}{l}-7.104 \\
(5.166) \\
\end{array}$ \\
\hline Constant & $\begin{array}{c}62.08^{* * *} \\
(1.704)\end{array}$ & $\begin{array}{c}60.96^{* * *} \\
(1.175)\end{array}$ & $\begin{array}{c}57.20^{* * *} \\
(0.645)\end{array}$ & $\begin{array}{c}50.46^{* * *} \\
(0.769)\end{array}$ & $\begin{array}{c}47.40^{* * *} \\
(0.555)\end{array}$ & $\begin{array}{c}41.59^{* * *} \\
(0.524)\end{array}$ & $\begin{array}{c}36.47^{* * *} \\
(0.406)\end{array}$ \\
\hline Observations & 1,846 & 2,868 & 6,010 & 4,499 & 5,903 & 4,660 & 3,815 \\
\hline R-squared & 0.046 & 0.021 & 0.015 & 0.023 & 0.037 & 0.021 & 0.073 \\
\hline \multicolumn{8}{|c|}{ Panel D: Number of Bathrooms } \\
\hline Close & $\begin{array}{c}-0.152^{* * *} \\
(0.0546)\end{array}$ & $\begin{array}{c}-0.607^{* * *} \\
(0.0575)\end{array}$ & $\begin{array}{l}-0.0277 \\
(0.0404)\end{array}$ & $\begin{array}{l}-0.0605 \\
(0.0439)\end{array}$ & $\begin{array}{l}0.135^{* * *} \\
(0.0471)\end{array}$ & $\begin{array}{c}0.0117 \\
(0.0559)\end{array}$ & $\begin{array}{c}-0.636^{* * *} \\
(0.0619)\end{array}$ \\
\hline After & $\begin{array}{l}0.293^{* * *} \\
(0.0769)\end{array}$ & $\begin{array}{l}0.252^{* * *} \\
(0.0577)\end{array}$ & $\begin{array}{l}0.214^{* * *} \\
(0.0329)\end{array}$ & $\begin{array}{l}0.242^{* * *} \\
(0.0454)\end{array}$ & $\begin{array}{l}0.138^{* * *} \\
(0.0313)\end{array}$ & $\begin{array}{l}0.192^{* * *} \\
(0.0396)\end{array}$ & $\begin{array}{l}0.119^{* * *} \\
(0.0375)\end{array}$ \\
\hline Close $\mathrm{x}$ After & $\begin{array}{c}-0.00759 \\
(0.104)\end{array}$ & $\begin{array}{l}-0.0730 \\
(0.0827)\end{array}$ & $\begin{array}{l}0.216^{* * *} \\
(0.0681)\end{array}$ & $\begin{array}{c}0.0396 \\
(0.0799)\end{array}$ & $\begin{array}{l}-0.0676 \\
(0.0891)\end{array}$ & $\begin{array}{c}-0.0771 \\
(0.119)\end{array}$ & $\begin{array}{c}0.178 \\
(0.167)\end{array}$ \\
\hline Constant & $\begin{array}{l}1.712^{* * *} \\
(0.0440)\end{array}$ & $\begin{array}{l}2.466^{* * *} \\
(0.0427)\end{array}$ & $\begin{array}{l}1.840^{* * *} \\
(0.0195)\end{array}$ & $\begin{array}{l}1.978^{* * *} \\
(0.0243)\end{array}$ & $\begin{array}{l}1.858^{* * *} \\
(0.0177)\end{array}$ & $\begin{array}{l}1.862^{* * *} \\
(0.0190)\end{array}$ & $\begin{array}{l}1.954^{* * *} \\
(0.0204)\end{array}$ \\
\hline Observations & 1,846 & 2,868 & 6,010 & 4,499 & 5,903 & 4,660 & 3,815 \\
\hline R-squared & 0.031 & 0.088 & 0.016 & 0.012 & 0.006 & 0.006 & 0.024 \\
\hline
\end{tabular}

Notes: Standard errors in parenthesis. Standard errors are heteroskeasticity robust and clustered to account for multiple sales of homes in the sample. ${ }^{* * *} \mathrm{p}<0.01,{ }^{* *} \mathrm{p}<0.05,{ }^{*} \mathrm{p}<0.1$ 
Panel B reports the estimates for lot size. In this case, the experimental effects estimates are small and not statistically significant for most of the stations. However, for Beacon Hill the estimate is positive and significant, and for Columbia City and Othello, it is negative and significant. The differences range from about 1/60th of an acre to about 1/100th of an acre, but in these neighborhoods the lots are typically quite small — around one-eighth of an acre for the Columbia City sample.

Panel C reports estimates for age. Again, the estimates for Beacon Hill are positive and statistically significant and for Columbia City and Othello they are negative and significant. Thus, the houses that are selling near Columbia City and Othello are disproportionately newer suggesting a relative influx of new housing around the Columbia City and Othello stations. The positive age effect for Beacon Hill suggests a relative influx of new housing in parts of the neighborhood that are not close to the stationthat the catchment area for the rail station is more stagnant with respect to new construction.

Panel D shows estimates for the number of bathrooms. The only statistically significant experimental effect is for Columbia City, and it is rather large at about .22.

Taken together, these estimates indicate that there have been rather significant changes in the composition of housing near the Columbia City station. It is possible that at least some of the large positive estimated impact of rail access in this neighborhood is due to significant changes in the composition of the housing stock in that neighborhood. For most of the other stations, it appears that there has been little or no difference between the catchment areas and more distant parts of the neighborhood in terms of the composition of the housing stock. Clearly, some caution is warranted in the interpretation of the results for the Columbia City station.

\section{Discussion}

Although many studies report beneficial impacts of light rail on property values, the mostly null (or negative) findings of this study are not unique. For example, Kim and Lahr (2014) study the impact of the Hudson-Bergen light rail line in Northern New Jersey using a repeat sales method that is similar to the differences-in-differences method used here. They find different effects for different stations, arguing that those neighborhoods that experienced the largest housing price appreciation were in areas that experienced much improved transit service. Housing near stations that were already well-served by public transit options experienced little or no benefit. Chatman, Tulach, and Kim (2012) find neutral to negative impact on housing prices of the River Line in the New Jersey suburbs of Philadelphia using a repeat-sales method. Also, using a model of longitudinal changes in housing prices, Papon, NguyenLuong, and Boucq (2015) found no beneficial impact of a new light rail line in Paris. Many of the crosssectional studies discussed by Higgins and Konaroglu (2016) also find negative proximity impacts of rail transit stations, but as explained earlier, it is difficult to interpret these results as causal as there may be reasons for light rail stations to be built in areas with depressed housing values.

Taking the estimates of the present study at face value, it suggests that the transportation benefit of the new light rail line in Seattle is small, or that non-transportation externalities, such as noise and higher auto congestion near stations, outweigh the benefits. While the public perception of light rail is that it is superior to systems based on buses, this is not necessarily the case, as Richmond (2005) argues in his analysis of the development of Los Angeles' light rail network. In particular, redesigning the bus transportation network to accommodate the fixed route of a rail line may significantly reduce the utility of public transit for many users (Richmond, 2001).

There are limitations to using this study as a basis for evaluating the total benefit of the new light rail service in Seattle. The study makes no attempt to estimate the benefits to users that do not live in the residential neighborhoods of the Rainier Valley. Due to limitations in the data, this study is unable to evaluate the impact of light rail service on apartment dwellers. Commercial properties in downtown ar- 
eas may also have benefited from the siting of light rail stations. Nor does this study address the benefits that may accrue to visitors to Seattle who use the rail line as a convenient way to access the downtown from the Sea Tac Airport. Furthermore, this analysis is based on the particular case of Seattle. Light rail lines in other cities may have higher or lower value. Each system needs to be considered on the basis of the characteristics of the system itself and those who use it.

\section{$9 \quad$ Conclusions}

This study examines the effect of new light rail service in Seattle on housing prices in the neighborhoods that it serves using a quasi-experimental technique, difference-in-differences regression. For the most part, it is reasonable to interpret these results as causal. There is little evidence that people who live in the neighborhoods surrounding light rail stations value the services that light rail provides on net. Except for the Columbia City neighborhood, the estimates indicate that houses that are most convenient to the light rail stations sell at a discount compared to what they would have sold for in the absence of light rail, although these differences are not statistically significant for four of the seven neighborhoods examined here.

While these results are specific to the city of Seattle and the light rail system that was constructed there, they call into question some of the optimism with which urban planners have embraced rail transit as a way to shape urban land use. In particular, these results indicate that transit financing systems that depend on a positive impact on land values from rail service may not be viable in typical United States cities.

\section{Acknowledgments}

The author wishes to acknowledge the helpful research assistance of Chit Pan Kwok and also recognize the helpful comments provided by the anonymous referees. 


\section{References}

Black, S. (1999). Do better schools matter? Parental valuation of elementary education. Quarterly Journal of Economics, 114(2), 577-599. doi: 10.1162/003355399556070

Chatman, D. G., Tulach, N. K., \& Kim, K. (2012). Evaluating the economic impacts of light rail by measuring home appreciation: A first look at New Jersey's River Line. Urban Studies, 49(3), 467487. doi: $10.1177 / 0042098011404933$

Federal Transit Authority. (2016). National Transit Database. January unedited file. Retrieved from https://www.transit.dot.gov/ntd/ntd-data

Figlio, D. N., \& Lucas, M. E. (2004). What's in a grade? School report cards and the housing market. American Economic Review, 94(3), 591-604. doi: 10.1257/0002828041464489

Guerra, E., \& Cervero, R. (2013). Is a half-mile circle the right standard for TODs? Access, 42, 18-21. Retrieved from https://www.accessmagazine.org/spring-2013/half-mile-circle-right-standard-tods/

Higgins, C. D., \& Kanaroglou. P. S. (2016). Forty years of modelling rapid transit's land value uplift in North America: Moving beyond the tip of the iceberg. Transport Reviews, 36(5), 610-634. doi.org/ 10.1080/01441647.2016.1174748

Kim, K., \& Lahr, M. L. (2014). The impact of Hudson-Bergen light rail line on residential property appreciation. Papers in Regional Science, 93(Supplement 1), S79-S97. doi: 10.1111/pirs. 12038

Lari, A., Levinson, D., Zhao, Z., Iacono, M., Aultman, S., Das, K. V., Junge, J., Larson, K., \& Scharenbroich, M. (2009). Value capture for transportation finance (research report). Minneapolis, MN: University of Minnesota, Center for Transportation Studies. Retrieved from http://www.cts.umn. edu/Research/featured/valuecapture/

Lindblom, M. (2016, April 23) 25-year wait for Sound Transit to finish light rail? Here's why. The Seattle Times. Retrieved from http://www.seattletimes.com/seattle-news/transportation/25-year-wait-forsound-transit-to-finish-light-rail-heres-why/

Papon, F., Nguyen-Luong, D., \& Boucq, E. (2015). Should any new light rail line provide real estate gains, or not? The case of the T3 line in Paris. Research in Transportation Economics, 49, 43-54. doi. org/10.1016/j.retrec.2015.04.005

Parmeter, C. F., \& Pope, J. C. (2012). Quasi-experiments and hedonic property value methods. In J. A. List \& M. K. Price (Eds.), Handbook of experimental economics and the environment (pp. 3-66). Cheltenham, England: Edward Elgar. ISBN 9781847205459.

Pope, D. G., \& Pope, J. C. (2015). When Walmart comes to town: Always low housing prices? Journal of Urban Economics, 87, 1-13. doi: 10.1016/j.jue.2014.10.004

Pryne, E. (2001, November 31). Sound Transit adopts 14-mile route; light-rail construction could start in summer. The Seattle Times. Retrieved from http://community.seattletimes.nwsource.com/archive l?date $=20011130 \&$ slug $=$ sound $30 \mathrm{~m} 0$

Pryne, E. (2002, March 15). Sound Transit gets green light to buy land for light rail. The Seattle Times. Retrieved from http://community.seattletimes.nwsource.com/archive/?date=20020315\&slug=soun $\mathrm{d} 15 \mathrm{~m}$

Richmond, J. (2001). A whole system approach to evaluating urban transit investments. Transport Reviews, 21(2), 141-179. doi.org/10.1080/01441640116962

Richmond, J. (2005). Transport of delight: The mythical conception of rail transit in Los Angeles. Akron, $\mathrm{OH}$ : The University of Akron Press.

Rosen, S. (1974). Hedonic prices and implicit markets: Product differentiation in pure competition. Journal of Political Economy, 82(1), 34-55. Retrieved from http://www.jstor.org/stable/1830899

Sound Transit. (no date). Regional transit history 1997-2003. Retrieved from http://www.soundtransit. org/About-Sound-Transit/News-and-events/Reports/1997---2003. 